\title{
Validating and improving elevation data of a satellite- image map of Filchner-Ronne Ice Shelf, Antarctica, with results from ERS-1
}

\author{
J. Sievers, \\ Institut für Angereandte Geodäsie, D-60598 Frankfurt am Main, Germany \\ C.S. M. DOAKE, \\ British Antarctic Survey, Natural Environment Research Council, Cambridge CB3 OET, England \\ J. IHDE, \\ Institut für Angewandte Geodäsie, D-(04105 Leipzig, Germany \\ D. R. MANTRIPP, \\ Mullard Space Science Laboratory, Holmbury St. Mary, Dorking, Surrey RH5 6VT, England \\ V.S. POZDEEV, \\ Seomorgeologija, St. Pelersburg 190121, Russia \\ B. RITTER, \\ Institut für Vermessungskuñde, Technische Unizersität, D-38106 Braunschweig, Germany \\ H. W. SCHENKE, \\ Alfred-Wegener-Institul für Polar- und Meeresforschung, D-27515 Bremerhazen, Germany \\ F. THYSSEN, \\ Forschungsstelle für Physikalische Glaziologie der Westfälischen Wilhelms-Lniversität Münster, D-48149 Münster, (iermany \\ D. G. VALGHAN \\ British Antartic Survey, Natural Emironment Research Council, Cambridge CBS OET, England
}

\begin{abstract}
A satellite-image map with surface-elevation contours of FilchnerRonne Ice Shelf has been published previously as a topographic map. The image map was constructed from a mosaic of 69 Landsat Multispectral Scanner (MSS) images and NOAA AVHRR data. The standard deviation in position in the central part of the mosaic is $\pm 125 \mathrm{~m}$. Topographic-glaciologic features were taken from Landsat scenes and represent the best coastline of this region. Surface elevations have been calculated from airborne and ground measurements of either ice thickness by assuming hydrostatic equilibrium or barometric pressure. Accuracies vary from \pm 2 to $\pm 7 \mathrm{~m}$. Oversnow trigonometric levelling in the northeastern part of the ice shelf, tied to sca level at the ice front, has given accuracies of $\pm 1 \mathrm{~m}$. Accuracies reduce to about $\pm 20 \mathrm{~m}$ in the grounded ice areas.

ERS-l radar-altimeter data over the ice shelf have been processed to give ellipsoidal heights (elevation above the ellipsoid). Geoidal reductions have been used to convert these to orthometric heights (elevation above sea level). No tidal corrections have been applied. The overall accuracy of the radar-altimeter-derived elevations is estimated to be better than $\pm 5 \mathrm{~m}$. There are noticeable differences from the topographic map in the central part where the radar data indicate a lower surface. However, the maps agree to within the stated error figures.
\end{abstract}

\section{INTRODUCTION}

Filchner-Ronne Ice Shelf is onc of the largest ice shelves in the world (Fig. 1). It covers an area of around $500000 \mathrm{~km}^{2}$, about the same as the Ross Ice Shelf, but has a higher average thickness and thus a greater volume.
The ice shelf influences global climate in two ways. First, melting of ice from the base of the ice shelf is a significant component of the Antarctic mass budget and the resulting modification of the sea water plays an important role in driving deep convection in the Southern Ocean, where about $80 \%$ of Antarctic Bottom Water is produced in the 


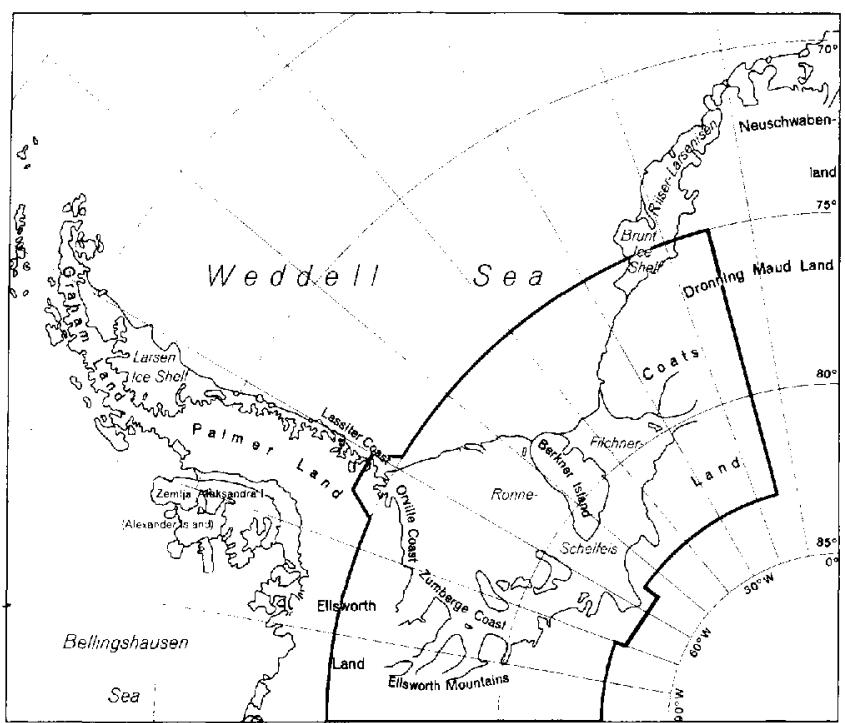

Fig. 1. Map sheet lines indicating the area covered by the Topographic Map (Salellite Image Map) 1:2000000 Filchner-Ronne Ice Shelf.

Weddell Sea region Jenkins, in press). Secondly, fastflowing ice strcams draining the Antarctic ice sheet disgorge into the ice shelf. Where the inland ice sheet is grounded below sea level, as in most of West Antarctica, one of the major problems is to understand the stabilizing rolc of the icc streams and the way this is influenced by the ice shelf. Accurate surface elevations reveal icc-shelf structures related to melting and freezing beneath it and are needed for numerical modelling studies of the icc dynamics.

The Filchner-Ronne Ice Shelf Programme (FRISP), formed in 1984 as a sub-group of the SCAR Working Group on Glaciology, co-ordinates glaciological activities of countries working in the region. Since the International Geophysical Year (IGY), 1957-58, significant work has been carried out by Argentina, Germany, Scandinavian countries, the U.K., the U.S.A. and the former U.S.S.R. As a result of a collaborative project between institutes in Gcrmany, the U.K. and Russia, the Institut für Angewandte Geodäsie (IFAG), Frankfurt am Main, has published a topographic map (1993) (a copy is enclosed in the end pocket of this volume) of the whole rcgion including the catchment area using the most recent surface-elcvation values from ground and airborne campaigns. A mosaic of Iandsat images has becn used as background, complementing a glaciological feature map produccd by an earlier collaborative exercise (Swithinbank and others, 1988). Surface elcvations derived from radaraltimeter data from the ERS-1 satellite fast-delivery product set over the ice shelf itself have been contoured to compare with the topographic map (1993).

A basic problcm in producing a surface-elevation map for the ice shelf is that there arc thick layers of marine ice (Oerter and others, 1992) beneath large parts of it which are sufficicntly absorbent to prevent the total ice thickness being sounded by radar methods (Crabtree and Doake, 1986; Thyssen, 1988). There could also be a mushy layer at the interface between the ocean and the ice-shelf base (Nicholls and others, 1991) which prevents seismic techniques from obtaining a distinct reflecting horizon. Thus, elevations cannot always be obtained by inverting icc thicknesses assuming hydrostatic equilibrium. Instead, elevations have to be derived using other techniques such as trigonometric or barometric levelling.

\section{TOPOGRAPHIC MAP (SATELLITE-IMAGE MAP) 1 : 2000000 FILCHNER-RONNE ICE SHELF}

\section{Satellite imagery}

To map the whole region of the Filchner-Ronne Ice Shelf as well as the contiguous catchment area, a digital mosaic of satellite imagery has been constructed to cartographic quality. The mosaic has becn assembled from 65 Landsat-4 and -5 Multispectral Scanner (MSS) scenes acquired between January 1985 and March 1988, four Landsat-1 and -2 MSS scenes acquired between October 1973 and February 1974, and NOAA AVHRR data acquired between 1980 and 1987 of areas not covered or not scanned cloud-free by the Landsat satellite.

Digital geometric construction of this mosaic is based on measurements of satellite-image coordinates of topographic features appearing in more than one Landsat scene. About 500 of these identical points ("tie points"), for which ground coordinates arc not known, have been used (Sievers and others, 1989). For referencing the image mosaic to the geographic map coordinate system, 28 ground-control points were available, positioned either by GPS or Doppler-satellite techniques. The standard deviation of coordinates of ground control and tie points is estimated to be $\pm 125 \mathrm{~m}$ in $x$ and $y$ positions. At the margins of the mosaic, especially at the southern boundary of the Filchner-Ronne Ice Shelf, the deviations are probably larger due to lack of ground control in this area.

Solar radiation reflected from the terrain surface is recorded by the MSS sensor in four spectral bands of the visible and near-infrared spectrum. Figure 2 shows that various types of snow and ice are equally discernible in all four MSS bands. This means that all relevant topographic-glaciologic information is contained in only one band. Band 3 was chosen for reproduction of the mosaic because of its greater evenness in the data recording of all

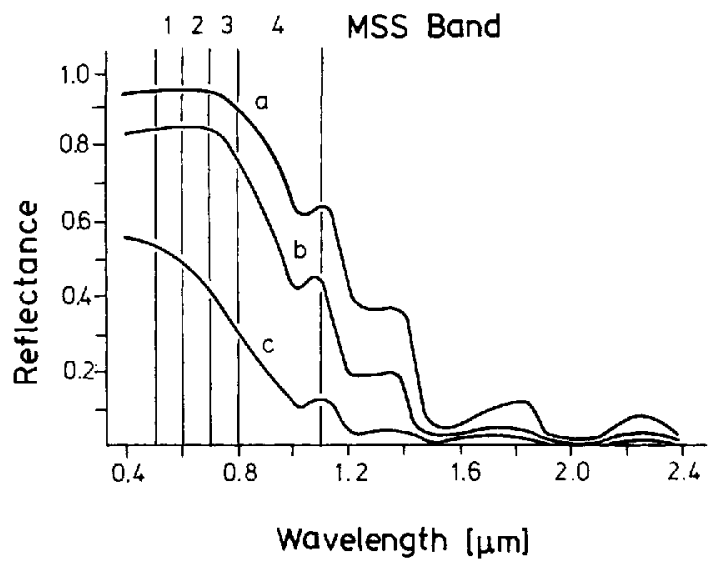

Fig. 2. Spectral reflectance of (a) dry new snow, (b) old snow and (c) blue ice (after Rott, 1989). 


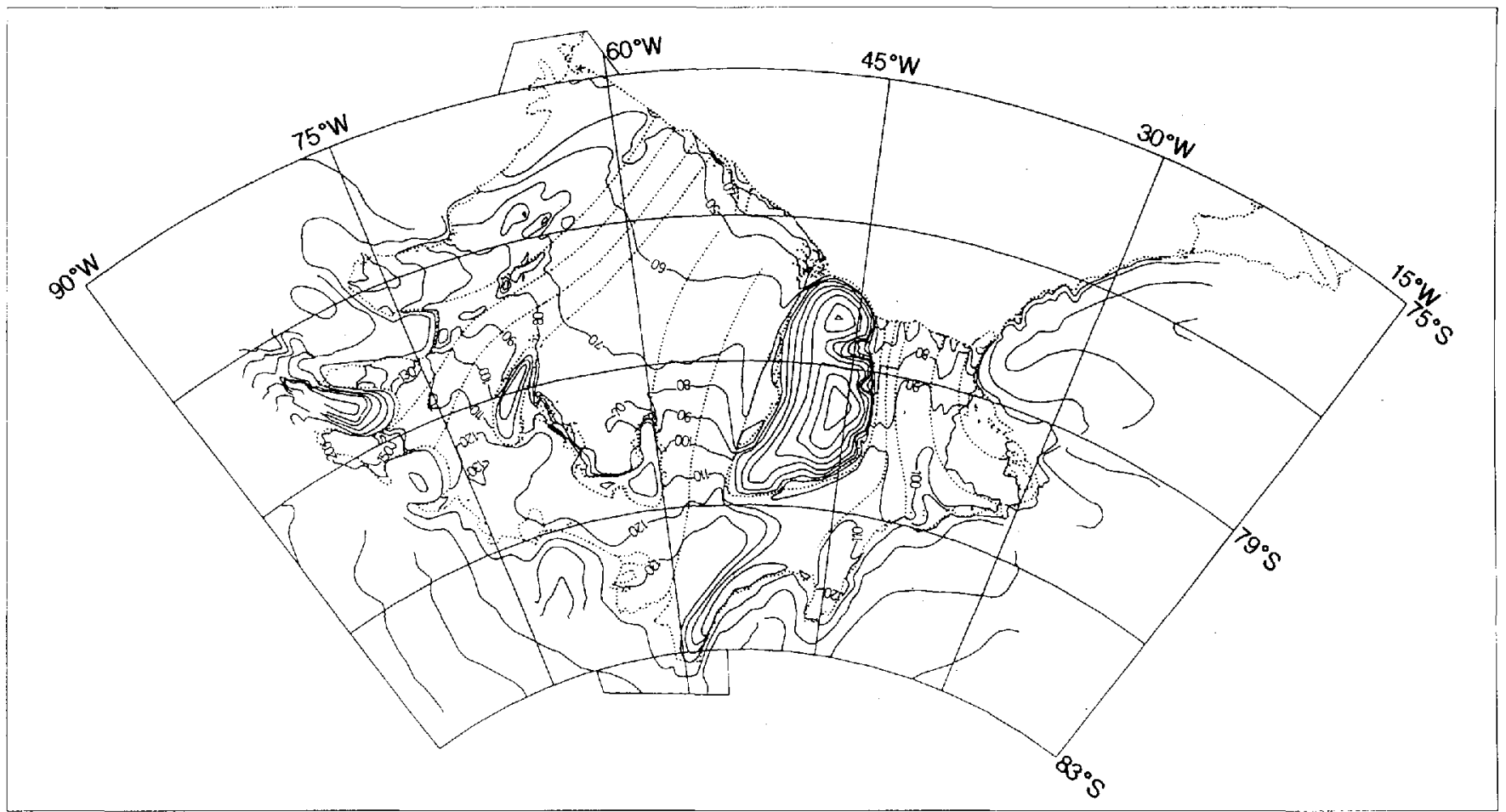

Fig. 3. Topographic features and surface-elevation contour lines as shown on the topographic map (1993).

images used (pcak of frequency and dynamic range of recorded reflected radiation). To handle the huge amount of digital data in the mosaic, the original pixel size $(60 \mathrm{~m}$ by $60 \mathrm{~m}$ ) had to be increased to a size of $240 \mathrm{~m}$ by $240 \mathrm{~m}$.

\section{Topographic-glaciologic data}

To aid map users in the interpretation of the satelliteimage mosaic, a selected number of topographicglaciologic features were cartographically represented on the image map and are shown in Figure 3. These are: the ice front as the seaward cliff of the ice shelf; the ice wall as the seaward cliff of the inland ice sheet or of the ice cap of an ice rise; the grounding line as the boundary between floating and grounded ice of the inland ice sheet or an ice rise, which on the topographic map (1993) is distinguished from the grounding line of ice rumples; the margins of glaciers or ice streams. Classification of the features was conducted by eye according to criteria developed by Heidrich and others (1992) on georeferenced satellite imagery enlarged to a 1:400000 scale. Digitization was carried out using a Geographic Information System. The number of features shown has been limited in order not to obscure details of the mosaic.

\section{Airborne and terrestrial elevation data}

Most of the elevation data used in the topographic map (1993), and shown in Figure 3, were previously unpublished. The most recent data available for a given area were selected for compilation, resulting in scven zones. The final data set was matched at the zone boundaries, contoured automatically and then smoothed by hand to reflect the morphology of the ice surface as revealed in the satellite imagery.

Surface-elevation data from airborne and ground measurements have been integrated from a number of sources. Airborne radar and barometric data collected by the scientific consortium Sevmorgeologija of the former Ministry of Geology of the U.S.S.R.), Sankt Pctcrburg, Russia, since 1976 were used as the base. Similar, but more recent, data from the Westfälische WilhelmsUniversität, Münster, Germany (Thyssen and others, 1992), and the British Antarctic Survey, Cambridge, England, were used in specific areas, particularly over the Ronne Ice Shelf. Where an unambiguous ice thickness was obtained, the elevations have been calculated by assuming hydrostatic equilibrium. The most difficult area in which to determine accurate elevations was the central part where there is the largest amount of basal ice accumulation. Only barometric measurements could be used, tied to trigonometric levelling where possible, and inconsistencies removed by a cross-over analysis. The determination of accuracies is described on the map. They vary from \pm 2 to $\pm 7 \mathrm{~m}$ on the ice shelf. Oversnow trigonometric levelling by the Technische Universität Braunschweig, Germany, in the northeastern part of the icc shelf, tied to sea level at the icc front, has given accuracies of $\pm 1 \mathrm{~m}$. Accuracies reduce 10 about $\pm 20 \mathrm{~m}$ in the groundcd-ice areas where elevations have been derived from barometric measurements made mainly during airborne surveys by the British Antarctic Survey, Cambridge, England; U.S. National Science Foundation, Washington, DG, L.S.A.; and Sevmorgeologija, Sankt Peterburg, Russia.

\section{RADAR-ALTIMETER DATA}

\section{Ellipsoidal heights (elevations above ellipsoid)}

The ERS-1 radar-altimeter data were taken from the fast-delivery products (ERSI.ALT.FDC) distributed 


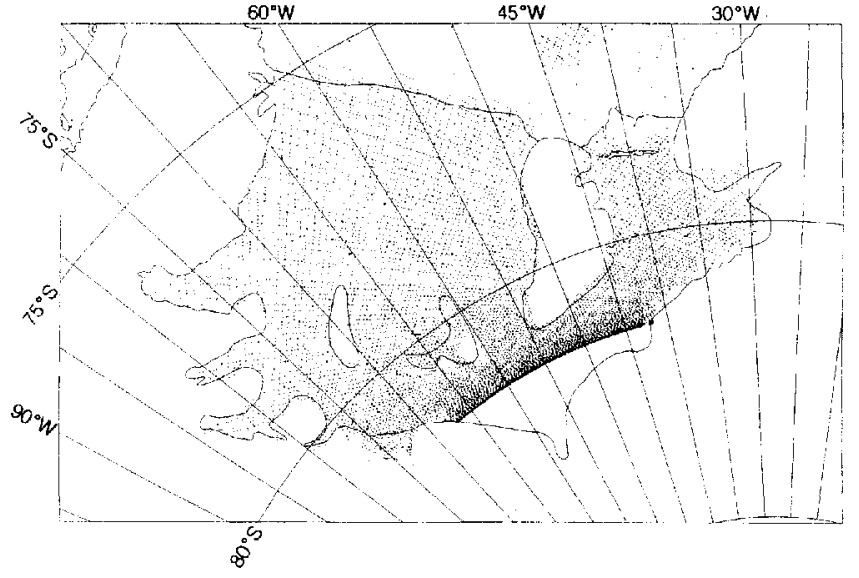

Fig. 4. ERS-1 radar-altimeter data points used from cycle-93 of the 35 d repeat orbit, January/February 1993.

by the European Space Agency (ESA). These products are processed directly by the ESA ground stations on reception of altimeter-telemetered data. They provide $1 \mathrm{~Hz}$ estimates of the fundamental parameters, including satellite to ground range, at an along-track ground spacing of $6.7 \mathrm{~km}$. The FDC products were postprocessed at the Mullard Space Science Laboratory (MSSL), England, to retrieve the best possible reference data set of ellipsoidal heights (i.e. height of data points above ellipsoid; Frei and others, 1993). First, the bad data points were filtered out using a "pulse peakiness" criterion developed by Strawbridge and Laxon (in press). The FDC parameter list includes a pulse-peakiness parameter, which describes the shape of the average of 20 altimeter wave forms, from which the elevation data given in the products are derived. The range data are taken from the on-board estimate, which is optimized for return-echo wave forms characteristic of ocean surfaces. It is assumed that, if the pulse-peakiness parameter exceeds a value of 1 , the on-board estimate is unreliable and hence the data point is discarded. The FDC data are distributed with the ERS-1 "restituted" orbit; we have replaced this with the more accurate "preliminary" orbit. Although atmospheric corrections are given in the products, they are rough estimates and of little value in the geographic area under consideration. No attempt was made to include a tidal correction. No slope correction was applied, as we are only interested here in the effectively flat ice shelf. In order to reduce the effects of weather, a single $35 \mathrm{~d}$ repeat data set was used, (cycle-93) from early 1993. Data points used from this cycle are shown in Figure 4. A bulk-quality assessment of the data set was carried out by applying a cross-over analysis technique similar to that described by Tai (1989). The residuals are of the order $\pm 1 \mathrm{~m}$ in the central area of the ice shelf, although they are higher around the grounding lines. A further increase in accuracy can only be achieved through analysis of the wave-form data set. The data set was interpolated using a bilinear method on to a $5 \mathrm{~km} \times 5 \mathrm{~km}$ grid, with a search radius of $7.5 \mathrm{~km}$ and a small along-track overlap, prior to conversion to orthometric height (elevation above sea level; Frei and others, 1993).

\section{Reductions to geoid}

Heights derived from radar altimetry must be converted to orthometric heights to be comparable with surface elevations on the topographic map (1993). The conversion was carricd out using the Geodetic Reference System 1980, GRS80 (Moritz, 1984), which has geometric parameters that are virtually identical to those of the WGS84 ellipsoid.

Ellipsoidal heights $H$ are related to orthometric heights $h$ for a given geoid $N$ by

$$
h=H-N \text {. }
$$

The geoid of the geopotential model (GPM) OSL91A (Rapp and others, 1991) was used for the reduction of the ellipsoidal heights. The OSU91A model is a spherical harmonic expansion of order 360 and thus resolves structures with wavelengths greater than $100 \mathrm{~km}$. Presently, it is the best available solution of a global GPM for the Antarctic region. The error of absolute geoidal heights in relation to the mean Earth ellipsoid is about $\pm 0.5 \mathrm{~m}$. The accuracy depends on the data introduced into the solution and thus is expected to be lower in the Antarctic regions.

The orthometric heights $h$ calculated according to Equation (1) have still to be shifted to sea level. The shift is to allow for two a priori unknown corrections: the difference between the geoid and the stationary seasurface topography and for the difference between the mean Earth ellipsoid and GRS80 (Frei and others, 1993). For determination of the shift parameter, comparisons with trignometrically levelled elevations on the Ronne Ice Shelf were used. From the comparisons, we obtained a difference of $\pm 2.0 \mathrm{~m}$ between the geoid and mean sea level of the Weddell Sea, so that the final relation for orthometric height $h^{\prime}$ is:

$$
h^{\prime}=H-N+2.0 \mathrm{~m} .
$$

The final results are shown in Figure 5. Our best estimate of the possible error of the elevations derived from the radar-altimeter data is $\pm 5 \mathrm{~m}$.

\section{COMPARISON OF RESULTS}

The overall comparison between the topographic map (1993) and the radar-altimeter data is within the indicated standard deviations, especially in areas where littlc marine ice has accumulated at the ice-shelf base. For example, the $50 \mathrm{~m}$ contour near the ice front on the Ronne Ice Shelf is similar in both cases. However, there are significant detailed differences in some areas, sometimes attributable to the different scales on which the data have been collected but sometimes reflecting the difficulty in obtaining accurate elevations from barometric heighting.

When compiling the topographic map (1993), in areas where we had competing data sets we chose the most recent set. In the case of the centre of the Ronne Ice Shelf, it meant that data processed by the Münster group wcre used in preference to data processed by Sevmorgeologija. There is perhaps a better correlation between the 
Sevmorgeologija data and the radar-altimeter data but the flatness of the area amplifies errors in elevation and could move contour positions substantially.

The $70 \mathrm{~m}$ contour illustrates the differences between the topographic map (1993) and radar-altimeter data well. There is agreement to within the quoted standard deviations from Berkner Island to $57^{\circ} \mathrm{W}$ and from $60^{\circ} \mathrm{W}$ to the Antarctic Peninsula. Between $57^{\circ}$ and $60^{\circ} \mathrm{W}$, the radar-altimetcr data show a disturbed zone in a trough running back from the ice front towards Korff Ice Rise, although a case could be made for drawing the $70 \mathrm{~m}$ contour in the position shown on the topographic map (1993). The overall trend from the radar data of a depressed central area is reminiscent of the meteoric icethickness distribution (Crabtree and Doake, 1986).

Downstream of F,vans Ice Stream, the topographic map (1993) shows a number of closed elevation loops which do not appear in the radar-altimeter data. These loops are located in an area with a narrow trough of basal marine ice and may be due to errors arising from the more complicated processing of barometric data from flights from several different seasons.

In most other areas, such as behind Korff and Henry Ice Rises on Ronne Ice Shclf and over Filchner Ice Shelf, there is an excellent agreement at the level of accuracy quoted for the topographic map (1993) and the radaraltimeter data.

\section{CONCLUSION}

At the $5 \mathrm{~m}$ level of accuracy, the contour lines on the published topographic map (1993) are equivalent to the ERS-1 fast-delivery radar-altimetcr-derived elevations. To improve the topographic map (1993) of derived elevations significantly, we require an order of magnitude better source of consistent data. This is most likely to be provided by ERS-1 radar altimetry once corrections for orbits, tides, ionosphere, atmosphere, surface, etc. are made. One source of error that will remain difficult to quantify is the gcoid reduction. The geoid gets worse away from the coast and for improvement requires a campaign of gravity measurements.

\section{ACKNOWLEDGEMENTS}

We should like to thank Dr P. Challenor (James Rennell Centre, Southampton) and Dr F. Strawbridge (MSSI.) for implementation of the Tai cross-over analysis algorithm.

\section{REFERENCES}

Crabtree, R. D. and C.S. M. Doake. 1986. Radio-echo investigations of Ronne Ice Shelf. Ann. Glaciol, 8, 37-41.

Frei, L., K. C. Graf and E. Meier. 1993. Gartographic reference systems. In Schreier, G., ed. SAR geucoding: data and systems. Karlsruhe Wichmann, 213-234.

Heidrich, B., J. Sievers, H.W. Schenke and M. Thicl. 1992. Digitale topngraphische Datenbank Antarktis. Nachr. Karten-Vermess, Reihe $1,107,127-140$

Institut für Angewandte Geodäsie. 1993. Topographic Map (Satellite Image Map) 1:2000000 Filchner-Ronne-Schelfeis, Antarktis. Frankfirt am Main, Institut lür Angewandte Geodäsie.

Jenkins, $\Lambda$. In press. The melting of continental ice in the occan and its impact on surface and bottom watcrs. In NATO Advanced Research Workshop, Aussis, France 1992.

Moritz, H. 1984. Geodetic Reference System 1980. Bulletin Géodesique (Paris), 58, 388 - 398.

Nicholls, K.W., K. Makinson and A.V. Robinson. 1991. Ocean circulation beneath the Ronne Ice Shelf, Antarctica. Nature, 354(6350), 221-223.

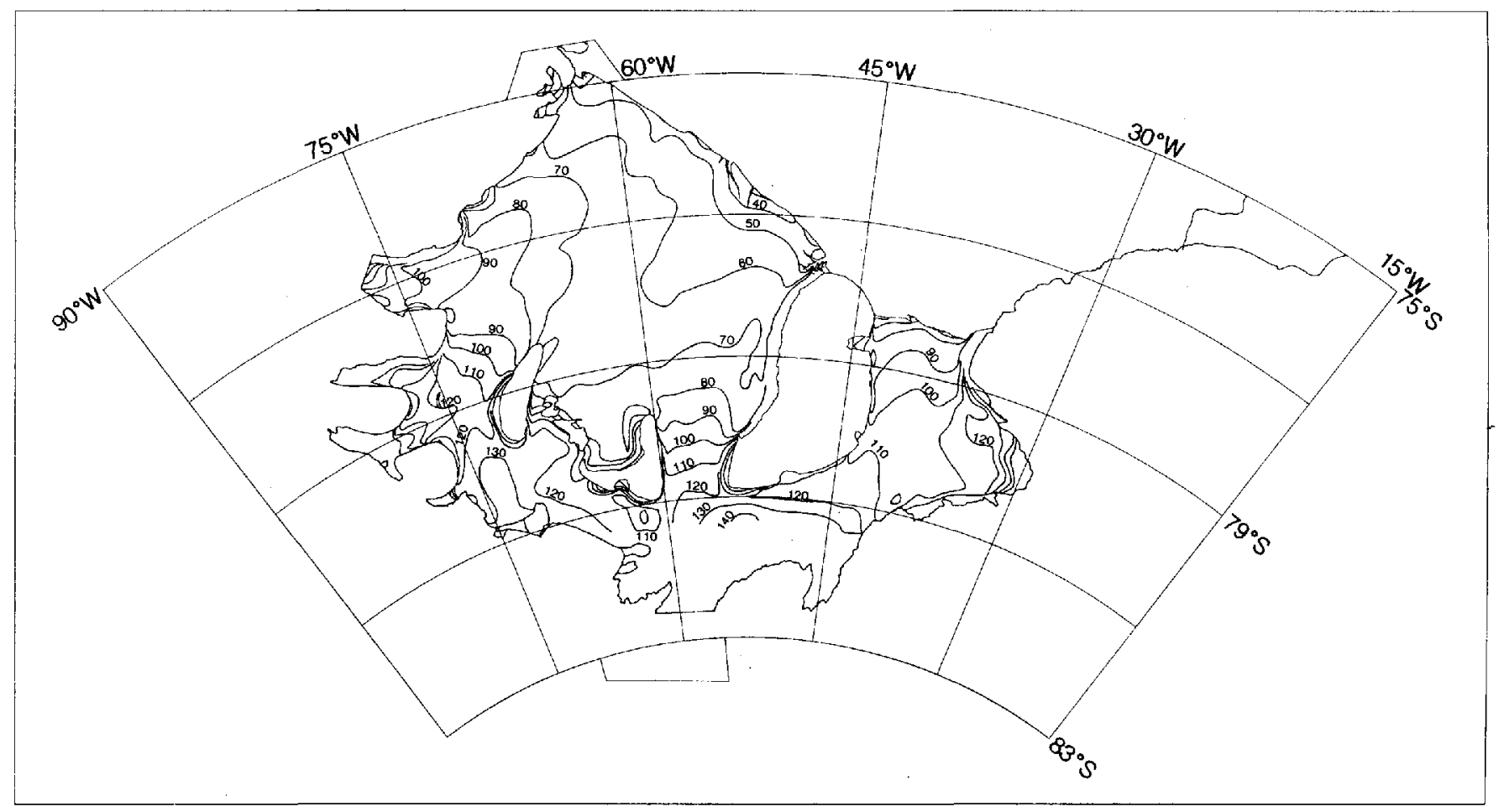

Fig. 5. Contoured orthometric elevations $(m)$ of Filchner-Ronne Ice Shelf derived from ERS-I radar-altimeter data and geopotential model OSU91A (Rapp and others, 1991). 
Oerter, H. and 6 others. 1992. Fvidence for basal marine icc in the Filchner Ronne Ice Shelf. Nature, 358(6385), 399-401.

Rapp, R.P., Y. M. Wang and N. K. Pavlis. 1991. The Ohio State 1991 geopotential and sea surface topography harmonic coefficient models. Columbus, OH. Ohio State University. Department of Goodctic Science and Surveying. (Report 410.)

Rott, H. 1989. Reflexionseigenschaften von Schnee und Eis. In Armberger, F., ed. Die Kartographie und ihre Randgebiete. Vol. IV/2. Wien, Deuticke, 345.

Sicvers, J., A. Grindel and W. Meier. 1989. Digital satellite image mapping of Antarctica. Polarforsthung, 59/1/2), 25-33.

Strawbridge, F. and S. Laxon. In press. ERS-1 altimeter fast delivery data quality flagging over land surfaces. Geophys. Res. Lett.

Swithinbank, C., K. Brunk and J. Sievers. 1988. A glaciological map of Filchner-Ronne Ice Shelf, Antarctica. Ann. Glawol, 11, 150-15.5.
Tai, C.-K. 1989. An efficient algorithm for computing the crossovers in satellite altimetry. Foumal of Amospheric and Oceanic Technology, 6, 13-18.

Thyssen, F. 1988. Special aspects of the central part of Filchner-Ronne Icc Shelf. Antarctica. Ann. Glaciol. 11, 173-179.

Thyssen, F., A. Bombosch and H. Sandhäger, 1992. Elevation, ice thickness and structure mark maps of the central part of the Filchner Ronne Ice Shelf. Polarforschung, 62 1), 17-26.

The accuracy of references in the lext and in this list is the responsibility of the authors, to whom queries should be addressed. 